\title{
Meeting the Writing Needs of Advanced ESL Learners
}

Elizabeth Bertoldi

This article describes a multi-faceted approach to meeting the writing needs of advanced ESL learners enrolled in an intensive, full-time ESL program lasting sixteen weeks.

The students are highly-motivated francophone managers and professionals who need to write memos, letters, reports, and other specialized material in English at work. Their writing is directed to employees, colleagues and superiors within a large bureaucracy, and to the public.

The article examines the theoretical and practical principles on which the writing course was based. In addition, it describes how learners' needs are met through the use of authentic documents and through individual teacher-student consultations.

How do you go about designing and teaching an advanced writing course to mature ESL learners with years of experience working in a bilingual workplace and with a variety of very diverse needs? This is the challenge I faced when I arrived at the Advanced Language Training Program of the Public Service Commission of Canada. The following article describes the writing course which evolved over two years of trial and error, research and experimentation.

\section{THE LEARNERS AND THEIR NEEDS}

The learners were French-speaking civil servants holding administrative or professional positions in a variety of departments from Agriculture to Justice to Transport. They ranged in age from 25 to over 45 . Some had worked in the National Capital Region of Ottawa-Hull for a number of years, while others had recently moved from Quebec, usually as the result of a major promotion. Their speaking ability ranged from intermediate to a near-native level. Their writing ability, as revealed by diagnostic testing, varied as well, but not in direct relation to their speaking ability. What they had in common was seriousness of purpose and high standards for themselves and others.

These far-from-ordinary language learners were enrolled in an equally unusal two-year program. They began with a four-month intensive, fulltime language course, which included tutorials designed to promote autonomy in language learning. The remaining twenty months were to 
be spent working in English in a position as similar to their own as possible, and as close to total immersion as possible. During this period they were expected to contact their tutor regularly to discuss progress, problems, and individual study plans.

The writing course that I had been asked to design and teach was part of the initial four-month phase. It had to bring the learners to a level where they could meet the demands of writing in their work environment, and it had to help them become more autonomous writers in English.

Through a needs analysis questionnaire, plus information from their employers, and discussion with the learners, I found that they had to write basically three types of documents: memoranda, letters, and reports.

Memos are used for written communication within a government department, usually to one's boss or one's staff. They are written for a multitude of purposes: to make or answer requests, to provide or ask for information, to make arrangements, to confirm conversations, to forward documents, etc.

Letters are used to communicate with the general public, usually to provide information or to respond to inquiries or requests. Letters are also used to correspond with other government departments, and to announce results of staffing competitions. Some departments use form letters; others publish extensive guides for letter-writing. Some civil servants also have to write letters for the signature of a superior, and have to keep in mind that person's preferred style and tone.

Reports vary in length from one page to a book-length document. However, length alone does not determine a report's importance. A onepage report could be a mundane account of the month's activities to one's immediate supervisor, or it could be an executive summary of an entire department's work over a 6-month period, and directed to the highest echelons of the government. Interestingly, reports are often the result of group collaboration, rather than the work of a single writer.

In addition to the three major types of writing, other needs emerged. Informal writing surfaced as a need within one's office or a department. Learners wanted to be able to write short notes on transmittal forms, scraps of paper, or yellow "stick-ons" to communicate informally with colleagues. At times, telephone messages also had to be written. More formal needs included translating. short documents from English or French, or reviewing the writing of others.

\section{PRACTICAL CONSIDERATIONS}

While the learners' general needs were similar, there were often vast differences in content, topic, and specialized vocabulary. Added to this 
was the wide range of writing proficiency in English. The time allotted to the writing course was limited to two two-hour classes per week, and the students' heavy workload precluded any outside classes or extra individual sessions.

In addition, very little appropriate material existed for these learners. The closest was a textbook, Administrative Writing (Larocque, Maclean \& Marshall, 1986), developed by the Public Service Commission specifically for intermediate level francophone civil servants. Since the language level was not advanced enough for my students, this textbook served as a springboard for further ideas, particularly concerning the influence of French on English and the importance of tone. Most other textbooks for advanced ESL writing are aimed at two major groups: foreign students preparing to study in English at British or American universities, or business people in international companies dealing with British or American firms. Where the academic texts dealt with expository writing, coherence, and transitional devices, they provided useful ideas, but the topics and contexts were usually inappropriate. With their emphasis on writing as a two-way communication process, the business texts were helpful, but the tone and purpose of business writing were often unsuitable for government writing.

Offsetting the constraints mentioned above was the fact that the learners were hard-working, highly-motivated and well-educated. Many were already fairly expert writers in French; they had developed ways of attacking a writing project; they knew how and when to revise or rewrite. In addition, they were all familiar with the format and purpose of government writing in French. Since many government documents are written in parallel English/French versions, they often had passive knowledge of bureaucratic writing in English. Thus, I was not starting from scratch with learners who had no idea of what writing was all about.

Part of the full-time language training also included a six-hour per week grammar course where basics such as verb tenses were reviewed and more complex areas such as articles, modals, gerunds, and reported speech were taught. This meant that I would not have to focus extensively on grammar in the writing course.

\section{FINDING A FRAMEWORK}

It became obvious that I needed a framework, some organizing principles, to structure these diverse elements into a workable whole. Krashen (1984) provided me with several valuable insights concerning comprehensible input, the composing process, and correction. According to Krashen, research findings indicate that extensive reading pro- 
vides the comprehensible input necessary for learners to acquire the code of written language, i.e., those conventions of vocabulary, style, and organization of the written form of English. Through their exposure to bilingual texts in the workplace, my students had already acquired the code of bureaucratic English to a certain extent. However, they needed greater familiarity with standard, fixed expressions; they needed to be able to manipulate language to create a certain tone, or to express ideas with tact; and they had to be able to write clearly and concisely.

However, since reading shows only the finished product, not the process by which it was achieved, Krashen indicates that writing instruction should initiate learners into the mental and physical processes of writing, including thinking, planning, writing, re-writing, re-reading, and if necessary, crumpling it all up and starting again. As competent writers in French and advanced ESL learners, my students generally did not need to be initiated into this process, but it seemed to me they could benefit from some discussion and reflection on the writing process, with perhaps some expansion of their existing repertoire of techniques.

Krashen also reports that traditional teacher correction of student writing, i.e., written comments on a final draft, has been shown to be of little or no help in improving writing. However, feedback between drafts has been found to be very helpful. The work of Graves (1983) and Clark (1985) also emphasizes the benefits of teacher-student conferences. Individual conferences seemed likely to provide me with a means of dealing with my students' different writing needs and levels of proficiency, as well as providing an opportunity for promoting autonomy through discussion of the composing process, and for the development of self-correction.

This background of needs analysis and review of research findings and their implications suggested that a writing course for these advanced learners should be based on authentic government writing and on individual teacher-student conferences.

\section{THE WRITING COURSE}

An outline of the course is presented in Figure 1. The course consisted of four sections: principles of effective writing, memos, reports, and letters.

The first section of the course, principles of effective writing, introduced learners to the approach to be used in the course, and explored the basic elements of good writing: clarity, conciseness, coherence, and appropriate tone. Authentic samples of government writing were selected to illustrate how these characteristics were achieved. In the conferences, learners' attitudes to writing were examined; in addition they 
were encouraged to refer to the personal file which I had asked them to collect from their own department in order to become familiar with good work-related writing.

The second section dealt with memos, the most frequently used means of internal communication. The communicative purposes of memos as well as the great variety of fixed expressions were explored in depth. During the conferences, learners are encouraged to identify recurring areas of difficulty and to take concrete steps to improve their memo-writing. Some learners found it useful to respond to actual memos in their own files.

Since government reports are so varied in content, length, and purpose, the third section of the course did not attempt to cover all possible formats, but instead concentrated more on the planning and organization needed to write a good report. There was a focus on conventions such as parallelism and the use of transitional devices. Here the course was closest to a traditional expository writing course. Since learners also wrote an extensive independent paper as part of their work for the Advanced Language Training Program, this section of the course had immediate as well as long-range applications. The individual conferences emphasized ways of organizing, writing, and revising the work in progress; learners reflected on their own strategies and learnt new ones.

The last section of the course proved to be an eye-opener for many learners since we examined not only traditional business letters, but also short notes and messages. These short notes were closer to informal spoken language than any other writing studied previously in the course. Many students were surprised at the compressed, almost telegraphic style, and the use of colloquial language. They had great fun "translating" formal memos into yellow "stick-on" messages, and vice versa.

As the writing program drew to an end, the focus in the conferences turned to how learners would exploit the resources of the work milieu in getting help with writing during their assignment in English.

Although there were differences in focus in each section of the course, each individual writing class followed a similar format. During each two-hour class, one hour was devoted to the reading and analysis of authentic samples of government writing. During the second hour, students worked individually on a writing assignment and, on a predetermined schedule, also met individually with me for a one-on-one writing conference.

\section{Using Authentic Documents}

As much as possible, I wanted learners to use authentic government writing as a source of comprehensible input; as samples of the language of bureaucratic writing and of the specialized writing of their individual 
departments; and as models for their own writing during the course and later on the job.

To obtain authentic samples, I drew on three sources. First, I began to collect all government memos, letters, reports, fliers, announcements, notices, etc. that crossed my desk. I also collected my own telephone messages, and any short notes written to me by my colleagues at work. Secondly, I went through the leftovers from a bank of government correspondence that had been collected and cleared for use in the development of other ESL writing courses. Finally, as mentioned earlier, I asked all incoming students to collect a file of letters, memos, and reports written by English-speaking members of their home departments. This file was to remain in the students' possession and to serve as a personal resource of specialized vocabulary, expressions, and style; it was also to serve as a standard of comparison for the learners' own writing in English. I was not going to try to inflict an idealized standard of what I thought good bureaucratic writing should be. I wanted the students to learn to write as well as their educated, articulate, native English-speaking peers.

These authentic samples of writing were used throughout the course, in particular in the first half of each writing class, where two or three samples were read and discussed. Students read silently and then through a series of questions analyzed such points as the communicative purpose, intended readership, tone, and possible impact of the piece of writing. This analysis was done either individually, or in pairs, followed by a whole-group discussion.

Learners then turned their attention to the specific language used in the samples. They analyzed the meaning of specific words and phrases and the levels of formality used; they discussed synonyms or alternatives for formulaic or idiomatic expressions; they became aware of the purpose of such techniques as parallelism, use of passive voice or modal auxiliaries. At all times, they kept in mind the question "Why did the writer use these words to convey this message to these particular readers?"

In the second half of the class, students used these models as a springboard to their own writing. In each class they were asked to begin writing a memo, letter, or report on a similar topic, keeping in mind the analysis just done. They were encouraged to refer to their own files for specialized vocabulary and phrasing.

\section{Individual Conferences}

It was during this ciass writing time that I arranged to meet learners individually for a conference. While this arrangement prevented me from circulating while students were writing, it gave me the opportunity to better meet individual needs. I set up a rotating schedule that allowed 
me to meet each student individually for 10-20 minutes during the regularly scheduled class time. Since classes contained a maximum of ten students, I was usually able to meet with students every week.

Learners brought along their writing at whatever stage it was. At times, they had nothing to "show" and we would discuss how they would start, select a topic, etc. Often, learners preferred to work on a different topic from the suggested one, and this was usually negotiated in favour of the student's individual needs. Some students did not want to show me their very first draft; they preferred to bring in their best-atthe-time effort.

During the conference, the learner retained physical possession of his/ her writing, and was encouraged to make changes and corrections on the spot by writing on the text. The student gave me a photocopy of the work afterwards. This technique encouraged the learner to retain responsibility for the piece of writing, and to be an active participant in the conference.

The learner might begin the conference by explaining the topic or situation, or by reading the text aloud. I would ask questions similar to the following to lead students to a self-analysis of their writing:

"How do you feel about this (piece of writing)?"

"Are you satisfied with it?"

"What kinds of problems did you have when you were writing?"

"Do you feel you've solved this/these problem(s)?"

"Can you think of any ways to improve this (part, section)?"

These questions led the student to identify a general area of difficulty and to suggest improvements. In early drafts, the problems might be those of organization or clarity. In later drafts, the focus might be on vocabulary choice, verbs, prepositions.

After this preliminary discussion, if I saw grammatical or other errors that the learner was unaware of, I might draw attention to them by stating:

e.g.: "I have a problem with this (expression, sentence, word).

Do you see what the problem is?"

If the learner did not recognize the error, I sometimes focused more directly by stating: e.g. "The verb is in the wrong tense," or "This is not the correct preposition." If the student could not correct after one or two tries, I supplied the correct answer.

The process described above aimed at helping learners gradually develop as autonomous, critical writers. Students were encouraged to revise and re-write as many drafts as necessary. The emphasis was on a quality product, not quantity. They were also encouraged to think of their writing as building a set of models for their own future use at work. 


\begin{tabular}{|c|c|c|c|}
\hline 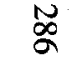 & WRITING COURSE & $\begin{array}{l}\text { USING AUTHENTIC } \\
\text { MATERIALS }\end{array}$ & $\begin{array}{l}\text { INDIVIDUAL } \\
\text { CONFERENCES }\end{array}$ \\
\hline & $\begin{array}{c}\text { I - Principles of } \\
\text { Effective Writing }\end{array}$ & $\begin{array}{l}\text { Focus on } \\
\text { - clarity } \\
\text { - conciseness } \\
\text { - coherence } \\
\text { - tone } \\
\text { in government writing, especially memos } \\
\& \text { letters }\end{array}$ & $\begin{array}{l}\text { Discussion of } \\
- \text { types of writing done } \\
\text { - attitude to writing } \\
\text { - objectives of a piece of writing } \\
\text { Learners encouraged to refer to own files for } \\
\text { ideas, models, vocabulary, style }\end{array}$ \\
\hline $\begin{array}{l}-1 \\
\stackrel{5}{6} \\
0\end{array}$ & II - Memos & $\begin{array}{l}\text { In-depth study of memos for } \\
\text { - informing } \\
\text { - responding } \\
\text { - action } \\
\text { - evaluating } \\
\text { Analysis of subject headings, importance } \\
\text { of tone }\end{array}$ & $\begin{array}{l}\text { Learners are encouraged to } \\
\text { - set own objectives } \\
\text { - analyse recurring patterns of difficulty } \\
\text { - consult native speakers for feedback }\end{array}$ \\
\hline 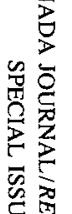 & III - Reports & $\begin{array}{l}\text { Types of government reports } \\
\text { Focus on } \\
\text { - planning, structure } \\
\text { - use of parallelism } \\
\text { - writing beginning and end } \\
\text { - transitional devices }\end{array}$ & $\begin{array}{l}\text { Learners choose subject of a short report, or } \\
\text { summary of a long report, to be completed } \\
\text { by end of Part III } \\
\text { Teacher provides feedback between drafts }\end{array}$ \\
\hline 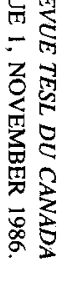 & IV - Letters & $\begin{array}{l}\text { Analysis of different types of letters for } \\
\text { - purpose } \\
\text { - psychological organization } \\
\text { - levels of formality } \\
\text { Focus on informal notes \& messages } \\
\text { including } \\
\text { - purposes } \\
\text { - characteristics } \\
\text { - language }\end{array}$ & $\begin{array}{l}\text { - Learners choose topics and may write real } \\
\text { letters } \\
\text { - C.V.s and covering letter are a popular } \\
\text { choice. } \\
\text { - Learners discuss how they will continue } \\
\text { improvement of writing after the course }\end{array}$ \\
\hline
\end{tabular}

Figure 1. Meeting the Writing Needs of Advanced ESL Learners. 
My preferred method of correcting students' work was via the techniques described in the individual conferences. At times, I used peer correction in student-student conferences. In general, peer correction was not very successful. Students had to be carefully matched as to ability and level of writing. Experience showed that students who write well and who are paired with an equally good partner participated well in student-student conferences and found them beneficial. Weaker students did not have confidence in their own or in another student's opinion. The fact that the learners were generally competitive, perfectionist and ambitious professionals may have made them especially sensitive to peer correction. Selecting "typical" errors from all the learners' writing turned out to be a useful and popular editing exercise for group work.

If, due to time or other constraints, I was not scheduled for a conference, a student sometimes submitted a draft for written comments. I always asked what specific kind of feedback was wanted, and gave that kind of feedback.

\section{Other Activities}

The writing course, while based primarily on the use of authentic writing and on individual conferences, also included other activities. Learners read about writing: for example, an excerpt from Krashen (1984) on "what is known about learning to write" helped explain the approach taken in the course; excerpts from business and government textbooks on writing provided insight into psychological organization, the "you" approach, and the need for tact. Learners also viewed management training films on writing designed for English-speaking managers. A colleague gave a series of in-class workshops on learning to edit one's own writing. A bilingual workshop on comparative stylistics given by the grammar teacher explored some basic differences in writing in English and French, and how similar ideas are expressed in very different grammatical structures in the two languages. All these activities helped familiarize learners with the organization and style of writing in English-writing which many had previously considered too blunt, too direct, even impolite, in comparison with writing in French.

\section{CONCLUSION}

The multi-faceted approach described above went a long way to meeting the writing needs of this group of learners. The approach built on the learners' expertise and experience, expanded their knowledge of the written code of government writing, and developed their ability to analyze and edit their own writing. However, the real test for learners 
came after the course, during the 20-month period of working in English. Learners were now required to write real letters, memos, or reports which would be read by English-speaking bosses, colleagues, and employees.

Contact with their tutors during this follow-up period indicated that the learners who made the greatest progress in writing were those who managed to enlist the help of an anglophone colleague (often in return for helping the colleague with his/her French writing). These more successful learners used the analysis and feedback techniques developed during the writing course to understand changes that were suggested to them. They were encouraged to ask their colleague how he/she would have written a particular sentence or paragraph, rather than asking for detailed grammatical explanations. In this way, they learned about departmental jargon and conventions, and about the varied possibilities of expression in written English. These learners made more progress than those who wrote in isolation, referring primarily to dictionaries, grammar books, or models written by anglophones.

By far the biggest challenge in the work environment was for a learner to review the writing of others, a formidable task even for some native speakers. While learners were usually able to comment quite confidently on content, clarity and conciseness, they still often felt insecure with the specific style or vocabulary of a piece of writing. Particularly if the writer being reviewed was also a francophone, an occasional wrong preposition or some "faux amis" might slip through into the final version.

However, in general, learners felt that the course had provided them with the tools for improving their writing at work. One learner went so far as to recommend the course to his anglophone colleagues to help them with their writing!

\section{REFERENCES}

Bander, R.G. (1978). American English rhetoric: a writing program in English as a second language (2nd ed.). New York: Holt, Rinehart \& Winston.

Clark, B.L. (1985). Talking about writing: a guide for tutor and teacher conferences. Ann Arbor: University of Michigan Press.

Corder, J.W., \& Avis, W. (1979). Handbook of current English. Toronto: Gage Publishing Co.

Cotton, D., \& Owen, R. (1980). Agenda: Workbook. London: Harrap.

Employment and Immigration Canada (1982). A practical guide to writing effective letters. Ottawa.

Graves, D. (1983). Writing: teachers and children at work. London: Heinemann.

Janis, J.H. (1978). Writing and communicating in business (3rd ed.). New York: MacMillan. 
Krashen, S.D. (1984). Writing: research, theory, and application. Oxford: Pergamon Institute.

Larocque, G., Maclean, H., \& Marshall, W. (1986). Administrative writing. Ottawa: Public Service Commission of Canada.

McKay, S. (Ed.). (1984). Composing in a second language. Rowley, Mass.: Newbury House.

Strunk, W., \& White, E.B. (1972). The elements of style (3rd ed.). New York: MacMillan.

Vaughan, K. (1981). Concise writing module. Montreal: McGill University.

Visco, L.J. (1981). The manager as an editor. Boston: CB1 Series in Management Communications.

\section{THE AUTHOR}

Elizabeth Bertoldi has taught ESL in Montreal and Ottawa, and has been involved in curriculum development and student resource centres. She is presently working as a tutor-manager in the Advanced Language Training Program (Public Service Commission) in Ottawa. 